\author{
Maya Vlahova-Angelova \\ Bulgarian Academy of Sciences
}

\title{
Colour terms in microtoponymy of Western Bulgaria (with special attention to metaphoric uses of colour terms)
}

\section{Introduction}

Colours have become significant problem in linguistics and related disciplines in last decades. Colours in different languages and cultures have been studied from linguistic, anthropological, psychological, cognitive perspectives. Some of most prominent scholars of our times dedicated their efforts to explaining this phenomenon. Colour terms (CTs) in the Slavic languages and cultures have also been investigated. These researches are concerned with semantics and origin of CTs, with their function and their uses. With respect to all this present article focuses on relation between CTs and microtoponymy. Bulgarian microtoponymy is abundant in names composed of CTs. These toponyms have not been studied so far. Their analysis could answer some important questions, which is the aim of this paper.

\section{Are CTs significant to toponymy and what is their role?}

Three facts concerning CTs could be regarded as relevant to toponymy and could be a starting point for a further research.

First, CTs occur frequently in microtoponymy. Second, apart from their concrete use in language, CTs are often used figuratively as symbols and metaphors. In other words, CTs have additional "non-colour" meanings. These "non-colour" meanings of CTs differ from language to language. They are not universal. They are linguistic expression of naïve thinking and thus they are specific for any culture. Moreover, microtoponymy reflects naïve thinking. It preserves local histories, customs, beliefs and everyday experience. As E. Pernishka points out "microtoponyms represent people's perception of the environment, people's lives and their figurative thinking" [2011: 31]. On that basis, I presume that the imagery of 
colours plays significant role in pattering of any local model of the Universe; that the use of CTs in microtoponymy goes beyond the concrete, literal pointing of certain physical characteristics of places to denoting some abstract concepts. Finally yet importantly, colours are very special kind of words, which bring usually up many associations. Some of these associations are constant, others - spontaneous. Present research aims at analyzing if associative thinking is involved in the process of name giving; if associative thinking motivates figurative use of CTs in microtoponymy and what figurative meaning CTs have in microtoponymy.

\section{Hypothesis}

Having into considerations what has already been said, the following hypothesis was formulated. Colours in microtoponymy play significant role in patterning the local model of the Universe. They refer to some places as consequence of various associations. CTs through their figurative use are linguistic expression of abstract naïve thinking. Thus microtoponymy indicates some basic mechanisms of analogical reasoning of language users. In other words, it is presumed that the notion of cleanness could be expressed by the term white or that the idea of danger/risk could be manifested by the term black in microtoponymy.

\section{Once again about the figurative use of CTs in language and in the Slavic languages in particular}

Reverting to the figurative meaning of colours the situation in the Slavic domain should be discussed. Australian slavist Peter Hill studied CTs in the Slavic Languages for a long time. In 2008 he published a paper The Metaphorical Use of Colour Terms in the Slavonic Languages summarizing his observations. Peter Hill's conclusions are relevant to the present research that is why I would like to comment them. He sticks to Berlin and Kay's theory of Basic Colour Terms, which was explicated in the book Basic colour terms. Their universality and evolution published in 1969. In order to make clearer Peter Hill's inferences this theory should be paraphrased in a few words. According to Berlin and Kay CTs are universal concepts. Every language can have only 11 basic colour terms: white, black, red, green, yellow, blue, brown, purple, pink, orange and grey, which arise in a particular order. First, black (dark) and white (light), then red, later yellow and green, later blue and brown etc. This theory was developed and thus basic colour categories have been subdivided to primary basic CTs: white, black, red, yellow, blue and green and derived basic CTs: purple, pink, orange, grey [Hill, 2008: 64]. The rest of CTs that occur in languages are regarded as Non-basic CTs: beige, azure, khaki etc. 
In his paper Peter Hill examines frequency of metaphorical uses of CTs in the Slavic languages. He concludes that primary basic CTs, such as black, white and red occur more frequently in metaphorical uses. In other words, those CTs that arise earlier in the hierarchy (proposed by Berlin and Kay) display more metaphorical uses than those that appear later. Further on, Peter Hill analyzes semantics of metaphorical meanings of CTs. He gives many examples from all Slavic languages and draws the following inferences: BLACK is associated with: unhappiness, sickness, poverty, Satan, shame, illegality, pessimism, bad luck; WHITE is associated with: beauty, absence of some quality, purification; WHITE and BLACK relate to such oppositions as: good - bad, happy - unhappy, healthy - sickly, hardworking - lazy; GREY symbolizes the absence of any positive qualities and has the most negative connotations of any colour term; RED has both positive and negative associations. It symbolizes life, but also anger, stormy feelings, love [Hill 2008: 66-77].

And last but not least, Peter Hill pays special attention to one particular metaphorical meaning of CTs - denoting cardinal directions. This issue is closely connected with the research on colours in Bulgarian microtoponymy that is why it is worth discussing it. In many cultures cardinal directions are associated with colours (especially in Asia). In this respect P. Hill connects some macrotoponyms on the Balkan peninsula with the eastern (Iranian) tradition via Turkish language: Черно море 'Black sea' = Northern sea, Бяло море 'Aegean sea' = Western sea. What is more, according to Ukrainian Soviet Encyclopedic Dictionary, issued in 1988, cardinal directions are specified by the means of CTs in the traditional Slavic cultures. The following scheme shows how the Slavs used to indicate directions: $\mathrm{N}=$ white, $\mathrm{E}=$ green, $\mathrm{S}=$ black, $\mathrm{W}=$ red. All this leads to the assumption that Bulgarian microtoponymy may also display similar relation between CTs and cardinal directions.

\section{Once again about the $\mathrm{CT}$ association potential}

As it was already mentioned, CTs bring up series of associations with other concepts. Some scholars [Almalech 2001] believe these associations form an additional, "non-colour" meaning of CTs, which is universal and transcultural. Mony Almalech, who studies colours in Bulgarian culture from different perspectives, conducted an empirical psychological research on CTs' associations in Bulgarian (2001). On the basis of series of experiments he managed to define the following statements:

- CTs have polysemic associations, i.e. one CT bring up several different associations

- Given CT has several antonym associations

- Given concept is associated with different CTs [Almalech 2001: 29] 
What is most important and it is closely related to the research on microtoponymy is the fact that CTs are often associated with abstract and metaphorical concepts regarding human feelings, emotions, attitudes etc: RED ${ }^{\circledR}$ passion, love, anger, hate; WHITE $®$ cleanness, immaculacy, honesty; BLACK $®$ sadness, sorrow, pain, misery; GREEN $\AA$ recreation, relax, youth, lack of experience [Almalech 2001: 31].

\section{Research algorithm}

Present research was conducted in accordance with the following algorithm. A corpus of tens of thousands microtoponyms was analysed. It comprises names from Western Bulgaria, the regions of Sofia, Vratsa, Montana, Dupnitsa, Berkovitsa, Radomir, Blagoevgrad, Samokov, Petrich, Tran, Breznik, Kyustendil.

1. Stage. Linguistic analysis of names

Microtoponyms have been analyzed according to the following criteria: a) type of onyms (oikomyns, hydronym etc.); b) kind of CT embedded in onyms (basic CT, non-basic CT) ${ }^{1}$; c) linguistic features of lexemes (standard, dialectal).

2. Stage. Semantic analysis of microtoponyms

This is the most important procedure of the whole research. Microtoponyms have been examined in order to distinguish literal and figurative meaning of CTs. As a result names comprising figuratively used CTs were collected. This was the main goal of the research.

\section{Results}

Formal linguistic analysis of microtoponyms composed of CTs from Western Bulgaria demonstrated that 5 groups can be determined according to toponym's type - oikonyms; anoikonyms; oronyms; hydronyms and dromonyms.

Examples:

Oikonyms: Бели брод, Бели извор, Бело поле, Бела Руска, Бела Турска, Зелениград, Зелен град, Мургаш, Пепелаш (Пепелеш), Цървен дол, Цървена ябука, Цървеняно, Червени брег, Ръджак, Ръждавииа.

Anoikonyms: Бела круша, Белещ, Бел орешак, Белио дрен, Бело брдо, Белио камен, Бела трева, Белото врълище, Белеш; Врано краище; Зелената ливада; Модрил, Синек, Синьо буче; Сури дол, Сери вльк; Червенак, Червена пърсь, Червена поляна, Цр(ъ)вено лище, Червено присое, Червенак, Червенииата, Червенухата, Червенуша, Цървена земя; Ръждевица; Риджаковото, Чърнио слог, Черна орница, Черни пень, Черното трънье.

${ }^{1}$ Describing colour concepts that occur in Bulgarian microtoponymy I use terms proposed by Berlin, Kay [1969]. 
Oronyms: Беласица, Бела кобила, Жълта стяна, Жлътата заредка, Жльтата хума, Зелена глава, Зелена грамада, Модри камик, Синио камен, Синя глава, Сиваците, Червен петел, Червен венеи, Червен лиляк, Черна гора, Цървен камен, Ръждавица.

Hydronyms: Бела вода, Белото кладенче, Белата пишура, Жльтата бара, Зелена бара, Зелен дол, Зелената локва, Модрето, Модреняко, Модрио кладенеи, Синята бара, Синия вир, Синио дол, Синята водица, Синьото езеро, Синьовеи, Синявецо, Сивио кладенеи, Сивака, Сивата вода, Серин дол, Червена ряка, Червена бара, Червени дол, Ръждавъи, Цръно блато, Църна локва, Черна, Черна река, Черни извор, Черни дел, Черналка, Чернатовеи, Чернел, Черниевеи, Черното пишурче, Чърнила.

Dromonyms: Белиа мост, Белиа път, Червения път, Чърния мост.

Further analysis regarding colour concepts, which occur in Bulgarian microtoponymy, supports Berlin \& Kay's theory. Only basic CTs appear in the toponymy of Western Bulgaria. Moreover, primary basic CTs are most frequent colour concepts to be found in toponymy of Western Bulgaria according to our corpus. As the examples demonstrate the biggest part of the names contain lexemes white, black and red. The rest of the primary basic CTs: green, blue and yellow occur much rarer in microtoponymy. It should be highlighted that the use of grey in Western Bulgarian microtoponymy is relatively high. This is the only derived basic $\mathrm{CT}$, which occurs in the corpus. There have not been found any microtoponyms comprising NON-BASIC CTs at all. It is worth mentioning that some descriptive colour concepts can also be seen in microtoponymy of Western Bulgaria such as: rusty, ashy, swarthy.

Linguistic analysis of onyms revealed that microtoponymy is rich in dialectal leximes designating colours. It is well known that microtoponymy reflects the local dialect. In this respect the use of: вран 'black', модър 'blue', сур 'grey', сер/ csp 'grey', cup 'grey' in Western Bulgarian toponymy is not surprising.

Examples: Враняк, Враньевица, Вранек, Модреяница, Модрил, Сурна земя, Суранииа, Сири дол, Сури дол, Сери влък.

Dialectal pronunciation of standard lexemes is another feature of microtoponymy. Pronunciation of standard words reflects all phonetic characteristics of Western Bulgarian dialects. That is why plenty of phonetic variants of black, red and yellow are seen in the corpus - чер: ирън: иърн: ичрн 'black'; червен: иръвен: иървен 'red'; жълт: жлът: жолт: желт: жлт: жут 'yellow'.

\section{Literal use of CTs in microtoponymy}

Semantic analysis of names showed that in the vast majority of toponyms CTs are used descriptively. In other words physical characteristics of sites motivated their names directly. Thus CTs are literal expressions of certain features and they correspond to the actual colour of the soil, rocks, plants, water etc. CTs do not change their lexical meaning in microtoponyms: Бела вода 'white water', 
Червена ряка 'red river' and Черна орница 'black fallow'. It should be emphasized that some of the names arise as analogies and comparisons. For example, given place is called Бела вода 'white water', since the water looks white, because it runs fast and foams along, or Зелена глава 'green head', because there is a forest and the peak looks green. In this respect it cannot be definitely concluded that those names do not display any mechanisms figurative thinking.

According to the objects that motivated toponyms 3 groups have been determined: a) microtoponyms motivated by the colour of the soil/rocks: Жлти камик, Жлткото, Чернел, Сивяк, Пепеливка, Ръждавъи, Белото врлище, Врано круше; b) microtoponyms motivated by the colour of the water: Синята водииа, Модрил, Черна река, Чврнила; c) microtoponyms motivated by the colour of the plants: Зеленище, Сивака, Црни връх, Сери влък, Црвената круша, Бела ябука.

\section{Figurative use of CTs in Bulgarian microtoponymy}

Taking into consideration what Almalech and Hill concluded about metaphorical use of CTs in language and mechanisms of associative perception of colours, plenty of similar uses of CTs were expected to be found in microtoponymy. Results were surprising. Very few examples of figurative use of CTs occurred in the whole corpus - less than 10: 1) Бели брод 'white ford' - an easy ford over the river Ogosta; 2) Бело поле 'white field' - a wide, spacious slope; 3) Белото присое 'the white spot' - southern slope with much sunshine; 4) Черна река 'black river' - a perilous river; 5) Черните дупки 'the black holes' - dark, frightful caves; 6) Чърния мост 'the black bridge' - a bridge where many people were killed in 1923; 7) Црна гора 'black forest' - a perilous forest.

As it can be seen, CTs do not keep their lexical meaning in these microtoponyms. They are used metaphorically. White means: easy, secure (1); wide, spacious (2); bright, light (3). On the contrary, black stands for: perilous and unforeseeable $(4,7)$; frightful (5); tragic, miserable (6). The examples show that metaphoric meanings of CTs in microtoponymy correspond to what P. Hill concluded about BLACK (= bad) and WHITE (= good). Moreover, these meanings are in accord with Almalech's assertion that BLACK associates with minor feelings, while WHITE - with cleanness. Nevertheless, these examples are insufficient.

\section{Conclusions}

In the beginning of my work, I have articulated a hypothesis that the naïve thinking of language users do not suffer from a lack of abstract reasoning. Mental lexicon has different levels of concrete and abstract terms, hyperonyms and hyponyms, which have vertical organization - generic terms and subordinate concepts. Toponymy is also a part of this taxonomy, but this is a folk-taxonomy, vernacular 
naming system. In our case, I focused on folk taxonomies. It is surprising that analysis of a corpus of more than 20000 place names did not reach a significant number of metaphoric and abstract uses of CTs in toponymy. Thus the hypothesis that abstract notions like cleaness, danger, beauty motivate and function as a source of analogical thinking, producing metaphors and figurative language, cannot be confirmed. There are no enough examples to prove the hypothesis that the white associates with light, cleanness, beauty and black - with the idea of danger. Obviously, the thinking in universal categories is characteristic for philosophical and logical thinking of some intellectual elites. Toponymy is related to the everyday knowledge and practical experience of ordinary language users. Our hypothesis summarizes that habitual thought provokes specific language uses connected with toponymy. CTs in toponymy are directly embedded in collective memory and refer to concrete objects and the features of their colour. Metaphors and abstract associations, as far as they exist, do not correspond to the sensitive experience gained in a particular place. In our very rare examples of abstract semantic motivation, we find a narrative structure - sometimes a short, sometimes a longer story. This legendary implicit context of the place names is more typical than the logical reasoning.

\section{References}

Almalech / Алмалех Мони, 2001, Цвят и слово. Психолингвистични и прагматични аспекти, София.

Berlin Brent, Kay Paul, 1991, Basic Color Terms: Their Universality and Evolution, Berkeley.

Hill Peter, 2008, The Metaphorical Use of Colour Terms in the Slavonic Languages, [in:] David N. Wells (ed.), Themes and Variations in Slavic Languages and Cultures. Australian Contributions to the XIV International Congress of Slavists, Perth, 62-83.

Pernishka / Пернишка Емилия, 2011, От погледа - към света и времето, [в:] Ангел Г. Ангелов, et al. (ред.), Проблеми на соииолингвистиката, t. 10, Езикът и соииалният опит, София, 29-34.

Ukrainian Soviet Encyclopedic Dictionary / Украинский советский энциклопедический словарь, 1988-1989, ред. Кудицкий Вера Александровна и др., т. 1-3, Киев.

\section{Bibliography}

Велев Вельо, 2009, Местните имена в Брезнишко, Велико Търново.

Велев Вельо, 2010, Местните имена в Пернишко, Велико Тьрново.

Иванов Йордан, 1982, Местните имена между Долна Струма и Долна Места, София.

Михайлова Димитрина, 1984, Местните имена в Михайловградско, София.

Михайлова Димитрина, 1986, Местните имена в Берковско, София.

Николов Богдан, 1997, Топонимията на врачанска околия, София.

Чолева-Димитрова Анна, 2009, Местните имена в Радомирско, София.

Електронна база данни на микротопонимията от Западна България, Институт за български език, БАН 
Maya Vlahova-Angelova

\title{
Colour terms in microtoponymy of Western Bulgaria (with special attention to metaphoric uses of colour terms)
}

\author{
(Summary)
}

Colours in microtoponymy play significant role in patterning the local model of the Universe. They refer to some places as a consequence of various associations. Colour terms via their figurative uses are linguistic expression of abstract naïve thinking. This study investigates if figurative meanings of colour terms are inherent in Bulgarian microtoponymy and what they stand for. In other words it tries to prove that in microtoponymy the notion of cleanness could be expressed by the term white or the idea of danger/risk could be manifested by the term black.

Słowa kluczowe: mikrotoponimia, użycie przenośne, nazwy kolorów, lokalny obraz świata.

Keywords: microtoponymy, figurative use, colour terms, local model of the Universe. 